\title{
Nutrients in the nexus
}

\author{
Eric A. Davidson ${ }^{1} \cdot$ Rachel L. Nifong ${ }^{1} \cdot$ Richard B. Ferguson $^{2}$ • \\ Cheryl Palm $^{3}$ - Deanna L. Osmond ${ }^{4}$. Jill S. Baron ${ }^{5}$
}

Published online: 15 February 2016

(C) The Author(s) 2016. This article is published with open access at Springerlink.com

\begin{abstract}
Synthetic nitrogen (N) fertilizer has enabled modern agriculture to greatly improve human nutrition during the twentieth century, but it has also created unintended human health and environmental pollution challenges for the twentyfirst century. Averaged globally, about half of the fertilizer-N applied to farms is removed with the crops, while the other half remains in the soil or is lost from farmers' fields, resulting in water and air pollution. As human population continues to grow and food security improves in the developing world, the dual development goals of producing more nutritious food with low pollution will require both technological and socioeconomic innovations in agriculture. Two case studies presented here, one in sub-Saharan Africa and the other in Midwestern United States, demonstrate how management of nutrients, water, and energy is inextricably linked in both small-scale and large-scale food production, and that science-based solutions to improve the efficiency of nutrient use can optimize food production while minimizing pollution. To achieve the needed large increases in nutrient use
\end{abstract}

Eric A. Davidson

edavidson@umces.edu

1 Appalachian Laboratory, University of Maryland Center for Environmental Science, Frostburg, MD 21532, USA

2 Department of Agronomy and Horticulture, University of Nebraska-Lincoln, Lincoln, NE 68583, USA

3 Agriculture and Food Security Center, The Earth Institute at Columbia University, 61 Route 9W, Palisades, NY 10964, USA

4 Soil Science Department, North Carolina State University, Box 7619, Raleigh, NC 27695, USA

5 U.S. Geological Survey, Fort Collins Science Center, Fort Collins, CO 80526, USA efficiency, however, technological developments must be accompanied by policies that recognize the complex economic and social factors affecting farmer decision-making and national policy priorities. Farmers need access to affordable nutrient supplies and support information, and the costs of improving efficiencies and avoiding pollution may need to be shared by society through innovative policies. Success will require interdisciplinary partnerships across public and private sectors, including farmers, private sector crop advisors, commodity supply chains, government agencies, university research and extension, and consumers.

Keywords Environment · Food security $\cdot$ Human health · Nitrogen $\cdot$ Pollution $\cdot$ Sustainable development

\section{Introduction}

Humans have profoundly altered the global nitrogen $(\mathrm{N})$ cycle in an effort to feed more than 7 billion people. Crops need $\mathrm{N}$ and other nutrients to grow, and increasing food and biofuel production from agriculture has required such large new inputs of nutrients that the amount of $\mathrm{N}$ circulating annually on land has more than doubled since the industrial revolution (Galloway et al. 2003). While this has led to greatly improved food security in much of the world, it also has unintended negative impacts when much of that additional $\mathrm{N}$ inadvertently is lost from agricultural fields, leading to widespread effects on downstream and downwind ecosystems. Nitrogen in fertilizer and manure that was intended to make crops grow better also causes harmful algal blooms when it enters water bodies, threatens human health when entering drinking water, and contributes to a variety of forms of air pollution that are human respiratory health hazards and climate-changing greenhouse gases (Davidson et al. 2012). While there have been important 
successes in recent decades in reducing $\mathrm{N}$ emissions to the atmosphere by industrial and transportation sectors, thereby improving air quality, effective solutions for reducing $\mathrm{N}$ and phosphorus losses from agriculture to groundwater and surface waters have been elusive. The knowledge and technology exist to improve the efficiency by which nutrients applied to agricultural land are utilized by crops rather than being lost as pollutants, but social, economic, and political factors have impeded their adoption (Davidson et al. 2015).

At the same time that $\mathrm{N}$ pollution from agriculture is a major problem in developed and emerging market countries, farmers in many developing nations do not have access to affordable fertilizers and sufficient quantities of manure. As a result, their crop yields are low, their families remain poorly nourished and economically disadvantaged, and the farmland soils degrade as they become depleted in essential nutrients (Sanchez and Swaminathan 2005). Although the nature of the challenges is different from those of managing an abundance of $\mathrm{N}$ in the developed world, increasing nutrient availability to farmers in the developing world is also primarily impeded by social, economic, and political factors.

Nitrogen management is a key component of the foodenergy-water nexus. Not only is $\mathrm{N}$ essential for food and biofuel production, the industrial synthesis of $\mathrm{N}$ fertilizers consumes energy and creates demand for fossil fuels. Moreover, the efficiency of $\mathrm{N}$ use in agriculture is closely tied to water management and water quality. Here, we provide case studies that include (1) intensively managed irrigated corn production in the American Midwest and (2) subsistence farming in rainfed corn production in sub-Saharan Africa. In both cases, understanding the synergies between nutrient and water management can improve the efficiency by which both are used, reduce energy demands, improve crop production, and lower pollution.

\section{The $\mathbf{N}$ cycle}

Nitrogen is an essential element for all life on earth, being a major ingredient of amino acids that make up proteins, RNA, and DNA. While elemental $\mathrm{N}$ is abundant, making up about $78 \%$ of earth's atmosphere as $\mathrm{N}_{2}$ gas, most of this $\mathrm{N}$ is unavailable to life (Galloway et al. 2003). High amounts of energy are required to sever the bond holding the two $\mathrm{N}$ atoms together; once broken, however, the $\mathrm{N}$ is incorporated into molecules that can be readily taken up and metabolized by microbes, plants, and animals, which we hereafter call "reactive-N." Prior to the industrial revolution, the energy to break apart the $\mathrm{N}_{2}$ bonds was supplied almost entirely by lightning or by $\mathrm{N}$-fixing microbes, which occurred at sufficiently low rates to make reactive-N in short supply and highly limiting to plant growth.

Today, more than half of the reactive- $\mathrm{N}$ in circulation on earth is produced through a human-engineered reaction called the Haber-Bosch process to make fertilizers, munitions, and other synthetic products. Large amounts of energy supplied by fossil fuel combustion are used to convert atmospheric $\mathrm{N}_{2}$ gas to ammonia $\left(\mathrm{NH}_{3}\right)$ under high temperature and pressures. Reactive-N is remarkably versatile, with various forms that can be taken up by plants and microbes, some of which are also highly mobile in soil solutions, surface and ground waters, and the atmosphere. The processes that convert one form of reactive- $\mathrm{N}$ to another, or convert it back to unreactive $\mathrm{N}_{2}$ gas, are collectively called the nitrogen cycle. In general, there are five main steps to the $\mathrm{N}$ cycle (Fig. 1). Nitrogen fixation converts $\mathrm{N}_{2}$ gas to $\mathrm{NH}_{3}$ or ammonium $\left(\mathrm{NH}_{4}{ }^{+}\right)$. Nitrification converts $\mathrm{NH}_{4}{ }^{+}$to nitrite $\left(\mathrm{NO}_{2}{ }^{-}\right)$and nitrate $\left(\mathrm{NO}_{3}{ }^{-}\right)$. Assimilation describes the uptake of $\mathrm{NH}_{3} / \mathrm{NH}_{4}{ }^{+}$or $\mathrm{NO}_{3}{ }^{-}$into biological tissues of plants, animals, and microbes to form organic molecules containing $\mathrm{N}$, such as amino acids. Ammonification converts organic-N back to $\mathrm{NH}_{3}$ and $\mathrm{NH}_{4}{ }^{+}$. Finally, denitrification and anaerobic ammonium oxidation (anammox) convert reactive- $\mathrm{N}$ back to $\mathrm{N}_{2}$ gas. Both nitrification and denitrification can allow small quantities of reactive$\mathrm{N}$ to escape to the atmosphere as nitric oxide (NO) and nitrous oxide $\left(\mathrm{N}_{2} \mathrm{O}\right)$ (Firestone and Davidson 1989).

\section{Agriculture and the $\mathbf{N}$ cascade}

A single molecule of reactive- $\mathrm{N}$ can be transferred between multiple ecosystems, from air to land to water and back again; these transfers and their environmental consequences are called the N cascade (Galloway 1998; Galloway et al. 2003). On average, about half of the reactive-N applied as fertilizer is incorporated into crops consumed by humans or feed for livestock; the other half may cycle through various forms in the soil but is eventually mostly released into the atmosphere or aquatic systems (Smil 1999, 2001; Galloway et al. 2003), thus initiating the cascade of unintended environmental and human health consequences. Released reactive-N can undergo multiple transformations, such as an ammonia molecule emitted by fertilized soil into the air can fall onto a coastal bay, where it is taken up by a harmful algal bloom, and then is released as ammonium, a fraction of which is converted to the greenhouse gas nitrous oxide by nitrifying bacteria, and so on, until the $\mathrm{N}$ is eventually converted back to innocuous $\mathrm{N}_{2}$. At each step in the cascade, reactive- $\mathrm{N}$ can cause negative environmental and human health consequences. Reactive-N has been shown to contribute to human disease and global climate change (Townsend et al. 2003; Erisman et al. 2011, 2013), cause stratospheric ozone depletion (Cowling et al. 1998; Ravishankara et al. 2009), acidify lakes and streams (Vitousek et al. 1997; Camargo and Alonso 2006), and lead to the eutrophication and habitat degradation of coastal systems (Howarth et al. 2000; Rabalais et al. 2002).

Although estimates at the global scale have a high degree of uncertainty, an approximate $\mathrm{N}$ budget for global agriculture 
Fig. 1 Diagram of the nitrogen cycle, showing transformations from unreactive $\mathrm{N}_{2}$ in the atmosphere to various forms of reactive- $\mathrm{N}$ and back to $\mathrm{N}_{2}$, including the processes of $\mathrm{N}$ fixation (lightning, biological $\mathrm{N}$ fixation, and the synthetic HaberBosch process), nitrification, assimilation in to plant, animal, and microbial biomass, ammonification, and denitrification/anammox. Atmospheric nitrous oxide $\left(\mathrm{N}_{2} \mathrm{O}\right)$ is produced as a byproduct of microbial nitrification and denitrification

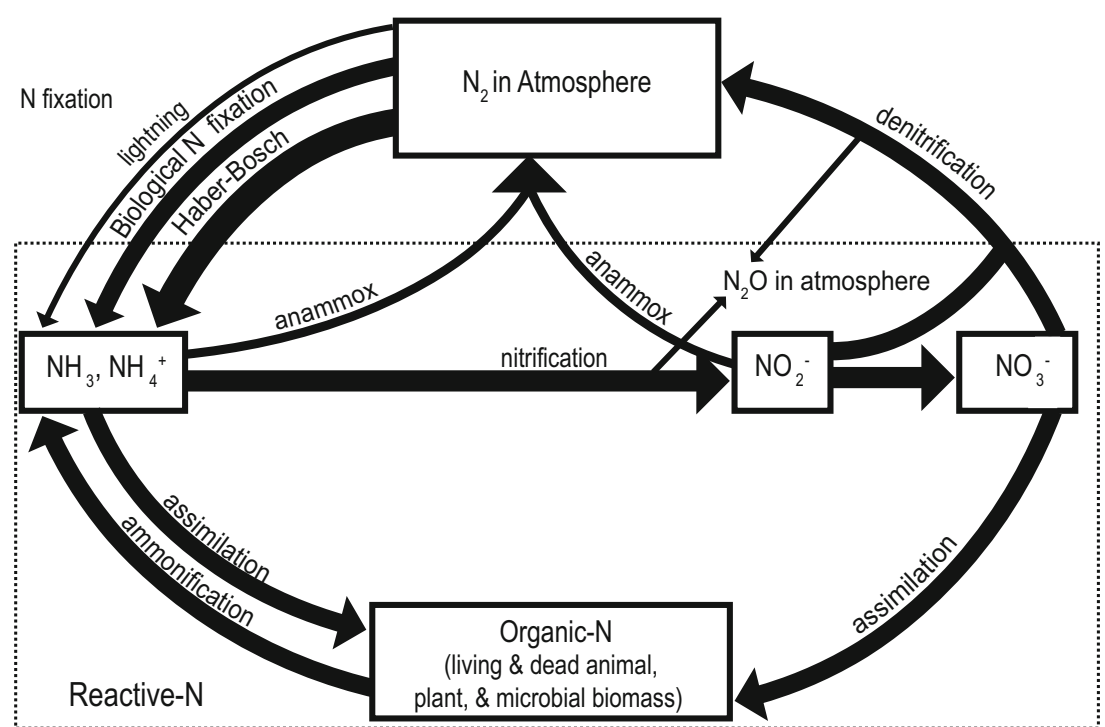

is presented in Fig. 2, showing that nearly $200 \mathrm{Tg} \mathrm{N}$ per year are cycled as reactive- $\mathrm{N}$ in agroecosystems around the globe. This budget appears arithmetically balanced, and in the real world, it must be balanced due to conservation of mass, but each of the specific flux estimates of $\mathrm{N}$ shown in the figure has an uncertainty of about $\pm 10-20 \%$ and possibly more owing to difficulties in measuring these fluxes and in scaling local measurements to global estimates. Despite such uncertainties in global estimates, it is clear than synthetic fertilizer inputs to agricultural systems, including livestock production, are larger than all natural $\mathrm{N}$ inputs combined (Bodirsky et al. 2014, Sutton et al. 2013). Of the estimated $122 \mathrm{Tg} \mathrm{N}$ in annual crop production, less than $20 \%$ goes directly to feed humans while the rest feeds livestock. The conversion of $\mathrm{N}$ inputs to livestock to edible $\mathrm{N}$ in the form of animal protein is even less efficient at approximately $7 \%$.

The $\mathrm{N}$ cascade can be mitigated by increasing the nutrient use efficiency (NUE) of crops and livestock production (Cassman et al. 2002) and by modifying dietary choices, which

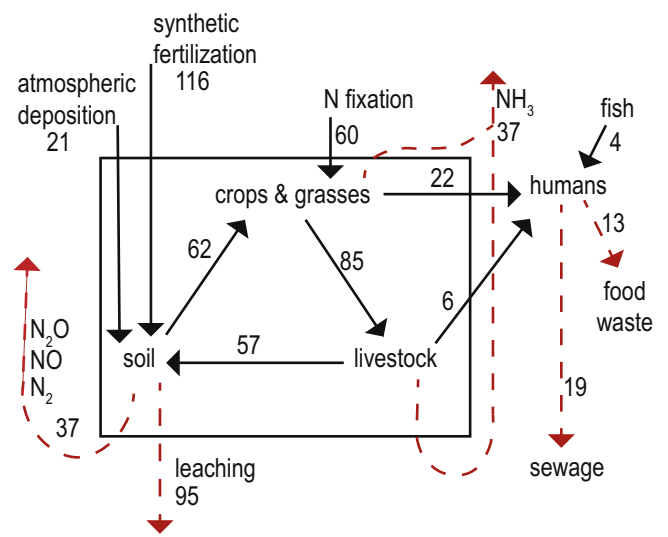

Fig. 2 Estimated annual $\mathrm{N}$ budget for global agriculture (based on estimates in Bodirsky et al. 2014, Sutton et al. 2013) Loss pathways are shown as reddashed lines while input and transfer pathways are depicted as black solid lines (color figure online) in turn, alter the $\mathrm{N}$ demand due to food production (Smil 2002). The following sections address how these losses to the environment can be mitigated by improving agronomic efficiency and human dietary choices. Two case studies, one in the US with intensive management of abundant $\mathrm{N}$ inputs, and one in sub-Saharan Africa with low intensity management of few $\mathrm{N}$ inputs, are used to illustrate the socio-economic challenges associated with mitigating the $\mathrm{N}$ cascade as well as prescribe policies to advance more food, low pollution (MoFoLoPo).

\section{The four Rs of nitrogen}

For decades, agronomists and soil scientists have made recommendations to farmers for $\mathrm{N}$ additions that included rate, source, timing, and placement. More recently, private and public organizations such as the United States Department of Agriculture-Natural Resource Conservation Service (USDANRCS) and private sector associations (e.g., the International Fertilizer Association (IFA), The Fertilizer Institute (TFI), and the International Plant Nutrition Institute (IPNI)) have begun to refer to these nutrient best management practices as the 4Rs - right rate, right source, right timing, and right placement.

Nitrogen rate determination varies based on crop, soil, climate, and region, which makes $\mathrm{N}$ recommendations difficult. Many US land-grant universities, for example, use yield goals and related $\mathrm{N}$ factors (yield per $\mathrm{kg} \mathrm{N}$ ) to develop $\mathrm{N}$ rate recommendations (Rajkovich et al. 2015). In several US Midwestern states (Illinois, Iowa, Minnesota, and Wisconsin), maximum return to N (MRTN) is used to make $\mathrm{N}$ rate recommendations (Sawyer et al. 2006) based on approximately $700 \mathrm{~N}$ rate trials from 1983 to 2004 from this region. The MRTN considers not only yield responses to fertilizer applications but also the economics of return on investment based on crop and fertilizer prices. However, this on- 
farm economic optimization of $\mathrm{N}$ use does not include the costs to society of off-farm pollution. Recently, sensors of crop foliar reflectance are being used to determine crop $\mathrm{N}$ sufficiency and appropriate growing season application rates which could increase nutrient use efficiency (NUE) and decrease losses of $\mathrm{N}$ to the environment.

Nitrogen sources are often determined by fertilizer availability as well as preference. Many farmers have begun to switch from anhydrous ammonium to urea ammonium nitrate (UAN) because the latter product is easier and safer to handle. Numerous products, such as Instinct $\AA$, AgrotainPlus ${ }^{\circledR}$, have been developed specifically to enhance NUE by actively retarding $\mathrm{N}$ transformations, thereby reducing $\mathrm{N}$ losses either through volatilization, nitrification, denitrification, or leaching; the literature on the effectiveness of these products, however, is mixed (Hatfield and Venterea 2014; Watts et al. 2014).

Finally, $\mathrm{N}$ application timing is critical to efficient uptake, and changing fertilizer source can also affect timing. As farmers have switched from anhydrous to UAN, they have also changed their timing; rather than applying the $\mathrm{N}$ in the fall or just once in the spring, many farmers have begun to split their application of $\mathrm{N}$. Splitting $\mathrm{N}$ applications over the growing season can increase NUE by ensuring that the $\mathrm{N}$ is available during active growth (Wuest and Cassman 1992), although split applications are usually more expensive and require more labor.

\section{Socio-economic impediments to adopting the 4Rs}

Understanding farmer decision-making is critical to understanding nutrient management adoption. In studies in the US, Prokopy et al. (2008) showed that no single attribute has been shown to regularly account for farmer adoption of nutrient best management practices (BMPs), but most of the studies they reviewed focused on farm structure (e.g., size of farm, rental acres, crops produced) and farmer demographic information (e.g., age, education, experience, income) rather than interviews that explored farmer decision-making per se. The use of $\mathrm{N}$ soil testing and test results were reviewed by Bosch et al. (1995) for fertilizer decision-making in a semiregulated area in Nebraska, and they found that the regulatory approach did not promote use of soil $\mathrm{N}$ test result; farmers needed more education along with regulation. Analyzing data from the USDA Agricultural Resource Management Survey (ARMS) of corn growers, Weber and McCann (2015) reported that of the 1840 observations, $27 \%$ of the farmers in the study received their application recommendations from a fertilizer retailer, whereas $50 \%$ said they did not receive any recommendations from anyone. In a survey of Illinois farmers, David et al. (2015) found that out of pocket expenses were quoted as being the greatest factor that limited farmers' ability and willingness to implement water quality nutrient management, followed closely by lack of government funds for cost sharing and concerns about reduced yields. They indicated that financial incentives and more readily available evidence to demonstrate effective local pollution reduction would have the greatest effect on adoption rates. Based on several farm surveys in North Carolina and a survey of farmers in 13 watersheds across the US, Osmond et al. (2014) showed that farmers generally did not fully apply nutrient management plans or follow basic soil test recommendations even when they had them. Farmers were found to be hesitant to apply N at university-recommended rates because they did not trust the recommendations, viewed abundant $\mathrm{N}$ as insurance, or used recommendations made by fertilizer dealers. Similar findings were reported by Stuart et al. (2014) for Michigan farmers, where fertilizer dealers and seed companies were critical sources in determining $\mathrm{N}$ fertilizer rates, while university recommendations and other tools were seldom relied on and often exceeded by farmers to increase yields when corn prices were high (Stuart et al. 2014).

Exceptions to these patterns have been noted when education, technical support, and funding resources focused on nutrient management included easing management demands, actively and consistently working directly with a small group of farmers, and providing both significant resource allocations to fund agency personnel and cost-share funds to farmers (Osmond et al. 2014). A significant disconnect exists between farmer behavior relative to nutrient management and its importance as the first line-of-defense in reducing agricultural nonpoint source pollution. Market forces on profits clearly affect adoption, but failures of current policies to promote improved nutrient management are also a function of programs failing to understand and address social and cultural forces. Understanding motivations for better nutrient use will require detailed key informant interviews that focus primarily on farmer nutrient management decision-making.

In sub-Saharan Africa, the majority of rural, farming households have been trapped in a vicious cycle of low nutrient inputs to crops, low crop yields, and poor health (Sanchez and Swaminathan 2005). Their poor health is usually linked to poor nutrition, more specifically chronic under nutrition, and the resulting decreased immunity to infectious diseases such as malaria (Black et al. 2008). Undernutrition and poor health also affect the ability to work on the farm, resulting in low agricultural productivity (World Bank 2006; Grosse and Roy 2008) and continued poor crop and soil management, leading to continued low yields and soil degradation (Fig. 3). It is increasingly recognized that these agricultural systems do not deliver sufficient essential nutrients to meet the dietary requirements (Graham 2008) and that better linkages between agriculture and nutrition need to be made (Carletto et al. 2015). 


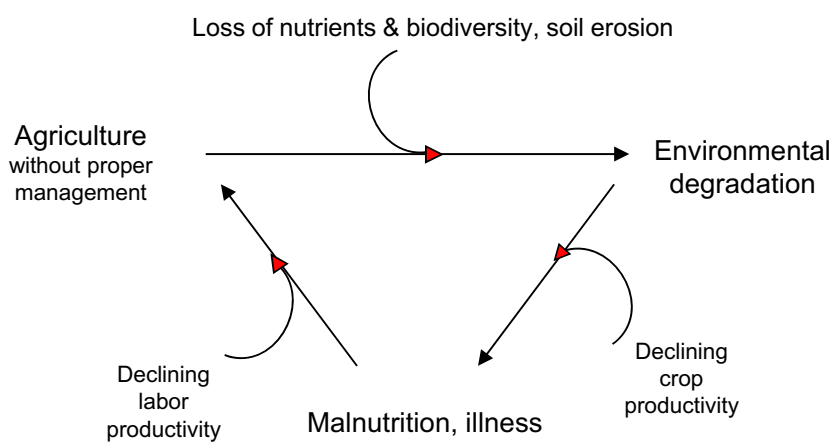

Fig. 3 Linkages between declining crop productivity, the decline in soil fertility, environmental degradation, and human nutrition and health (modified from Deckelbaum et al. 2006)

Lack of protein in the diet due to lack of $\mathrm{N}$ in farming systems has been dramatically demonstrated by Liu et al. (2010). They show that the amount of $\mathrm{N}$ input to soils in sub-Saharan Africa on a per capita basis is insufficient to produce the amount of protein needed for the population; they associate this with the high levels of undernutrition in the region. The concept of "econutrition," linking agricultural productivity, environmental sustainability, and human nutrition, suggests that this negative cycle can be reversed by increasing agricultural productivity and diversity in these degraded areas. Econutrition can have additive effects on soils, ecosystem services, and human nutrition and productivity (Deckelbaum et al. 2006). The high cost of fertilizers in subSaharan Africa, often two to six times that of the cost on other continents, is one of the main reasons for the lack of nutrient inputs to crops in the region (Sanchez and Swaminathan 2005).

\section{Case study 1: farmer engagement in intensive, irrigated crop production in Nebraska, USA}

In Nebraska's Central Platte River Valley, irrigated crop production grew rapidly from the 1950s through the 1970s, with corn as the predominate crop. The combination of intensive irrigated corn production, using relatively high $\mathrm{N}$ fertilizer rates, along with shallow aquifers and often shallow, coarsetextured soils, led to leaching of nitrate into groundwater resources. The first documentation in this region of $\mathrm{NO}_{3}-\mathrm{N}$ levels in excess of the $10-\mathrm{mg} \mathrm{L}^{-1}$ drinking water standard was in 1961 (University of Nebraska Extension Service 1965). By the early 1980s, large areas of groundwater with $\mathrm{NO}_{3}-\mathrm{N}$ greater than $10 \mathrm{mg} \mathrm{L}^{-1}$ were common in the Central Platte Valley.

Natural Resources Districts (NRDs) are local, watershedbased government entities in Nebraska charged with managing and protecting natural resources, including groundwater (Korus et al. 2013). Each NRD has a locally elected board of directors who set policy for the district. In 1987, legislation was passed by the Nebraska state legislature to allow NRDs to establish groundwater management areas (GWMAs) to protect water quality. The first GWMA was established in 1988 by the Central Platte Natural Resources District (CPNRD) to address what had become widespread areas of high $\mathrm{NO}_{3}-\mathrm{N}$ groundwater in the Central Platte Valley. The CPNRDGWMA today includes four phases with increasing severity of $\mathrm{NO}_{3}-\mathrm{N}$ contamination, and corresponding levels of restriction and practice adoption (Central Platte Natural Resources District 2014; Table 1). Additional details of the CPNRDGWMA regulations are provided by Exner et al. (2010).

Along with and even prior to implementation of GWMA regulations, the CPNRD conducted an educational effort in conjunction with the University of Nebraska-Lincoln (UNL) to encourage adoption of $\mathrm{N}$ fertilizer and irrigation best management practices (BMPs). Educational efforts began in 1979 and have expanded across the entire district since, continuing to date (Ferguson 2015). Educational efforts often involved demonstrations on grower fields of recommended practices, including use of the UNL N recommendation algorithm to predict optimal fertilizer $\mathrm{N}$ rate (Shapiro et al. 2008), scheduling irrigation according to crop water use, use of irrigation flowmeters to calculate water application rates, and the use of nitrification inhibitors to reduce $\mathrm{NO}_{3}-\mathrm{N}$ leaching. Treatments on demonstration fields were typically randomized and replicated field-length strips, implemented by the cooperating producer in collaboration with a project technologist. Summer field days and winter grower meetings were used to disseminate results from demonstration sites.

In phase 2 and 3 areas of the CPNRD-GWMA, reports filed by producers have resulted in a large database of producer practices and resulting impacts on grain yield, fertilizer use efficiency, and groundwater quality. Figure 4 illustrates trends in nitrogen use efficiency calculated as partial factor productivity for nitrogen $\left(\mathrm{PFP}_{\mathrm{N}}\right)(\mathrm{kg}$ grain produced per $\mathrm{kg}$ fertilizer $\mathrm{N})$. The statewide $\mathrm{PFP}_{\mathrm{N}}$ is calculated from corn grain production in Nebraska documented by the United States Department of Agriculture National Agricultural Statistics Service (USDA-NASS) and surveyed fertilizer $\mathrm{N}$ rates for corn (USDA-NASS, 2014). Statewide trends from 1965 through 2012 show a steady increase in $\mathrm{PFP}_{\mathrm{N}}$ over this time-from approximately $35 \mathrm{~kg}$ grain $\mathrm{kg} \mathrm{N}^{-1}$ in 1967 to $65 \mathrm{~kg}$ grain $\mathrm{kg}$ $\mathrm{N}^{-1}$ in 2010. This steady gain in efficiency is likely due to a wide range of factors, including adoption of improved $\mathrm{N}$ management practices such as accounting for $\mathrm{N}$ credits (soil residual $\mathrm{N}$, legumes, irrigation water, manure, mineralization from organic matter), increased use of split application timing, realistic expected yields, and economically based $\mathrm{N}$ rate recommendations, along with improved cultivars and other production practices. The $\mathrm{PFP}_{\mathrm{N}}$ for the CPNRD-GWMA was calculated from fertilizer $\mathrm{N}$ rates and grain yield reported by producers in phase 2 and 3 areas. Generally, producers in the CPNRD-GWMA area were already using $\mathrm{N}$ fertilizer more efficiently than average producers statewide in 1988, when 
Table 1 Phased regulations for the Central Platte Natural Resources District Groundwater Management Areas

\begin{tabular}{|c|c|c|}
\hline Phase & Average groundwater $\mathrm{NO}_{3}-\mathrm{N}$ & Restrictions \\
\hline I & $\leq 7.5 \mathrm{mg} \mathrm{N} \mathrm{L}^{-1}$ & No fall $\mathrm{N}$ fertilizer applied on sandy soils \\
\hline II & $7.6-15.0 \mathrm{mg} \mathrm{N} \mathrm{L}^{-1}$ & $\begin{array}{l}\text { No fall fertilizer application on any soils; annual tests of } \mathrm{NO}_{3}-\mathrm{N} \text { in soil and irrigation water; } \\
\text { analyze samples of manure applied for } \mathrm{N} \text {; consider soil residual } \mathrm{NO}_{3}-\mathrm{N} \text {, irrigation water } \\
\mathrm{NO}_{3}-\mathrm{N} \text {, manure, and previous legume crop } \mathrm{N} \text { credits in calculating } \mathrm{N} \text { fertilizer rates; be } \\
\text { certified by the NRD in fertilizer and irrigation management every } 4 \text { years; measure } \\
\text { irrigation water applied to each field; annual reporting for each field, including crop yield, } \\
\text { all soil and water tests, } \mathrm{N} \text { credits, recommended and actual fertilizer rates, use of } \\
\text { nitrification inhibitors, and irrigation water applied }\end{array}$ \\
\hline III & $>15.0 \mathrm{mg} \mathrm{N} \mathrm{L}^{-1}$ & $\begin{array}{l}\text { Requirement of phase II plus required use of an approved nitrification inhibitor or split } \\
\text { application of } \mathrm{N} \text { during the growing season for rates in excess of } 56 \mathrm{~kg} \mathrm{~N} \mathrm{ha}^{-1}\end{array}$ \\
\hline IV & No improving trend or worsening trend & CPNRD sets the expected yield and therefore the $\mathrm{N}$ fertilizer rate (no cases yet) \\
\hline
\end{tabular}

the GWMA was implemented $-60 \mathrm{~kg}$ grain $\mathrm{kg} \mathrm{N}^{-1}$ in the CPNRD-GWMA vs $49 \mathrm{~kg}$ grain $\mathrm{kg} \mathrm{N}^{-1}$ statewide. However, there has been little gain in $\mathrm{PFP}_{\mathrm{N}}$ in the CPNRD-GWMA in 25 years since it was implemented. In 2012, both statewide and CPNRD-GWMA PFP ${ }_{\mathrm{N}}$ were around $65 \mathrm{~kg}$ grain $\mathrm{kg} \mathrm{N}^{-1}$. Also, statewide $\mathrm{PFP}_{\mathrm{N}}$ appears to have been relatively static at around $65 \mathrm{~kg}$ grain $\mathrm{kg} \mathrm{N}^{-1}$ over the last decade or so. Collectively, these trends suggest that CPNRD-GWMA producers had begun to adopt more efficient $\mathrm{N}$ use practices in the 1980s, and that statewide producers have gradually caught up with CPNRD-GWMA producers in terms of $\mathrm{N}$ use efficiency. The data also suggests that perhaps $\mathrm{N}$ fertilizer management practices most used by producers may be reaching a limit in terms of further gains in $\mathrm{PFP}_{\mathrm{N}}$.

Figure 5 illustrates trends in groundwater and soil residual $\mathrm{NO}_{3}-\mathrm{N}$ from phase 2 and 3 area producer reports. Since the implementation of the CPNRD-GWMA in 1988, there has been a steady decline in groundwater and soil $\mathrm{NO}_{3}-\mathrm{N}$, on average a decline of $0.15 \mathrm{mg} \mathrm{L}^{-1} \mathrm{NO}_{3}-\mathrm{N}$ year ${ }^{-1}$ in groundwater.

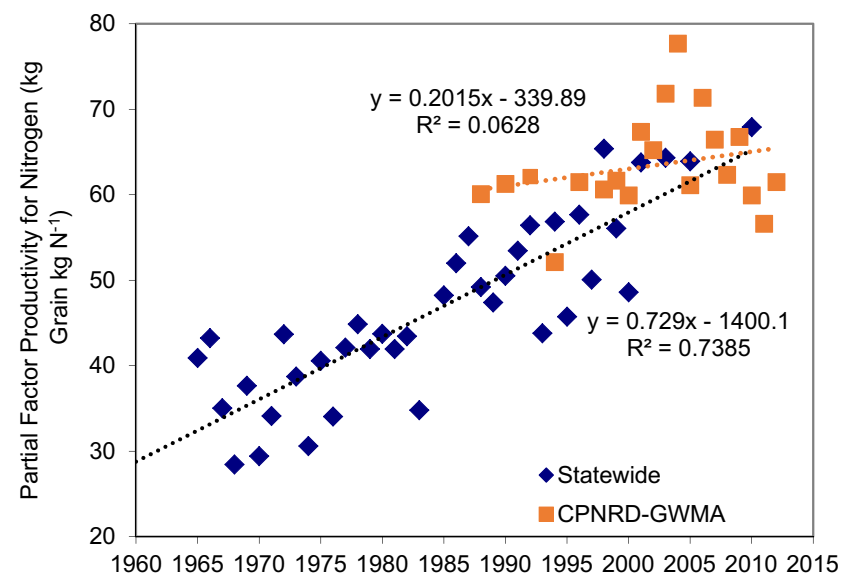

Fig. 4 Partial factor productivity for $\mathrm{N}\left(\mathrm{kg}\right.$ grain $\mathrm{kg}$ fertilizer $\left.\mathrm{N}^{-1}\right)$ in Nebraska. Statewide calculated from United States Department of Agriculture National Agricultural Statistics Service (USDA-NASS 2014) corn production and Agricultural Resource Management Survey data; Central Platte Natural Resources District Groundwater Management Area (CPNRD-GWMA) data calculated from phase 2 and 3 area producer reports
These trends indicate that irrigation and fertilizer management practices adopted by farmers in the CPNRD- GWMA have had positive environmental impact. Exner et al. (2010) found that the primary driver of reduced nitrate concentration in groundwater in a phase 3 portion of the CPNRD-GWMA was conversion of furrow-irrigated land to sprinkler irrigation. While $\mathrm{PFP}_{\mathrm{N}}$ has remained relatively static since inception of the CPNRDGWMA, leaching pressure has declined with more efficient irrigation methods, leading to declines in groundwater $\mathrm{NO}_{3}-\mathrm{N}$ levels. This result illustrates how the integration of nutrient and water management can have synergistic benefits.

While trends shown in Fig. 5 are encouraging, there are still issues of concern. The average groundwater $\mathrm{NO}_{3}-\mathrm{N}$ in phase 2 and 3 areas was still $15 \mathrm{mg} \mathrm{L}^{-1}$ in 2012-well above the drinking water standard. It is unknown to what level $\mathrm{NO}_{3}-\mathrm{N}$ concentrations in groundwater can be reduced using current approaches. In addition, Fig. 4 suggests that gains in $\mathrm{PFP}_{\mathrm{N}}$ may be leveling off with current practices used by the majority of producers. To achieve further gains, extension efforts have begun to focus on encouraging adoption of the next generation of BMPs - especially for irrigated corn production. Growers

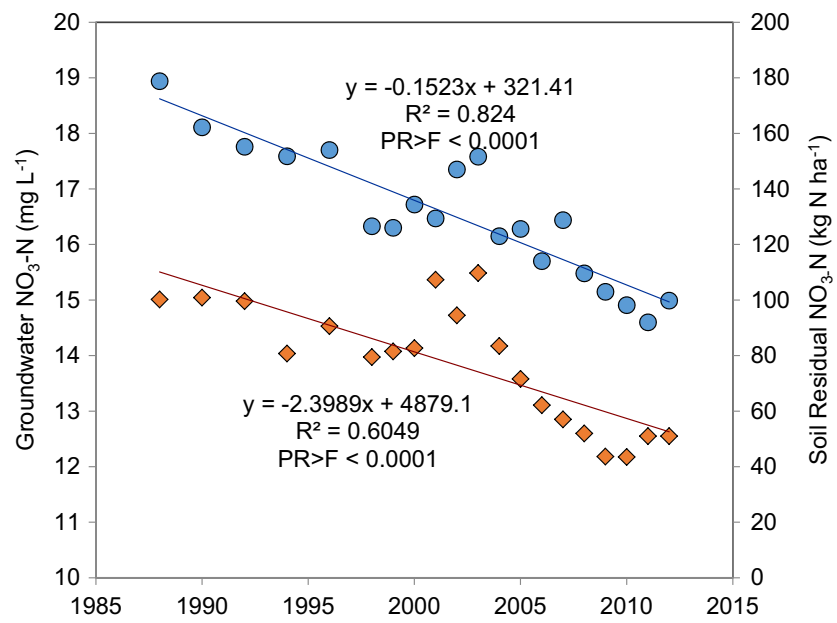

Fig. 5 Groundwater $\mathrm{NO}_{3}-\mathrm{N}$ (circles) and soil residual $\mathrm{NO}_{3}-\mathrm{N}$ (diamonds), Central Platte Natural Resources District-Groundwater Management Area (CPNRD-GWMA), 1988-2012 (from Ferguson 2015) 
are increasingly using soil moisture and crop water use sensors to manage irrigation. Because nitrogen use efficiency and water use efficiency are tightly coupled, timely information, in some cases, geospatial information, on soil water availability and crop water use allows much more efficient irrigation management and can reduce the risk of $\mathrm{NO}_{3}-\mathrm{N}$ leaching. Fertilizer $\mathrm{N}$ application during the growing season is encouraged, rather than fall or spring preplant application. In Nebraska, May and June are the highest rainfall months. By delaying significant $\mathrm{N}$ fertilization until midJune or later helps prevent leaching or denitrification loss during this period. The use of crop canopy sensors is being encouraged, which adjust the rate of $\mathrm{N}$ fertilizer on-the-go from a highclearance fertilizer applicator, based on crop $\mathrm{N}$ status during the V8-V12 (emergence of the 8th to 12th leaf) growth period of rapid $\mathrm{N}$ uptake (Abendroth et al. 2011). Crop canopy sensors allow both $\mathrm{N}$ fertilizer timing and rate to be optimized for improved $\mathrm{N}$ use efficiency. Project SENSE (Sensors for Efficient Nitrogen Use and Stewardship of the Environment) was initiated in 2015 in Nebraska to encourage producers to shift towards inseason $\mathrm{N}$ fertilization. Project SENSE is a joint effort of the UNL On-Farm Research Network, the Nebraska Corn Board, five Natural Resources Districts, and the USDA National Institute of Food and Agriculture. Future approaches for intensive irrigated production systems in Nebraska are likely to integrate soil and crop sensors, mounted either on drones, high-clearance applicators, or on center pivot irrigation systems themselves, using integrated sensor approaches for controlling inputs of $\mathrm{N}$ and water in both space and time. Such approaches will further help irrigated crop growers optimize input use efficiency and profitability, while minimizing environmental impact.

\section{Case study 2: nutrient supply and crop resilience in rain-fed sub-Saharan African agriculture}

The African Green Revolution was launched in 2004 to address multiple issues associated with low crop yields in Africa. The first among the interventions was increasing access to fertilizers and improved crop seeds; this recommendation included the provision of subsidies to make fertilizers more affordable. The country of Malawi introduced a national subsidy program in 2005, providing vouchers for one bag of urea and one bag of diammonium phosphate fertilizers - for one acre of land. Within a few years, there was dramatic increase in food production, primarily maize (Denning et al. 2009). Although there is not yet conclusive evidence that this has led to decreased undernutrition in Malawi, a study of several sites in Africa showed increased food security and diet diversity three years after a fertilizer subsidy program was introduced (Remans et al. 2011). Other interventions had also been introduced at these sites but agriculture subsidies and increased crop production had been realized from the first year (Sanchez et al. 2007). Several other countries in sub-Saharan Africa, including Nigeria, Tanzania, Kenya, have also introduced fertilizer subsidies for smallholder farmers. These programs have met with varying success and are costly for the governments to maintain.

The nutrient use efficiency (NUE) of fertilizer applications on these depleted soils is quite low, yielding only $12 \mathrm{~kg}$ of grain per $\mathrm{kg}$ of $\mathrm{N}$ applied (Dorward et al. 2008). Part of the low uptake by the crop is due to fertilizer recommendations that are not appropriate for the crop or soil system or other soil factors limiting crop growth, including possible soil compaction, micronutrient deficiencies, and the need to apply lime (Vanlauwe et al. 2015). This low use efficiency means a waste of very limited funds paid by smaller holder farmers. After the initial boost of nutrients with mineral fertilizers that is needed to increase crop production in these nutrient depleted soils, a more holistic stepwise approach can be taken to improve NUE and crop productivity. This approach is called integrated soil fertility management or ISFM (Vanlauwe et al. 2015; Fig. 6). A key component of this approach is the use of organic inputs to complement the mineral

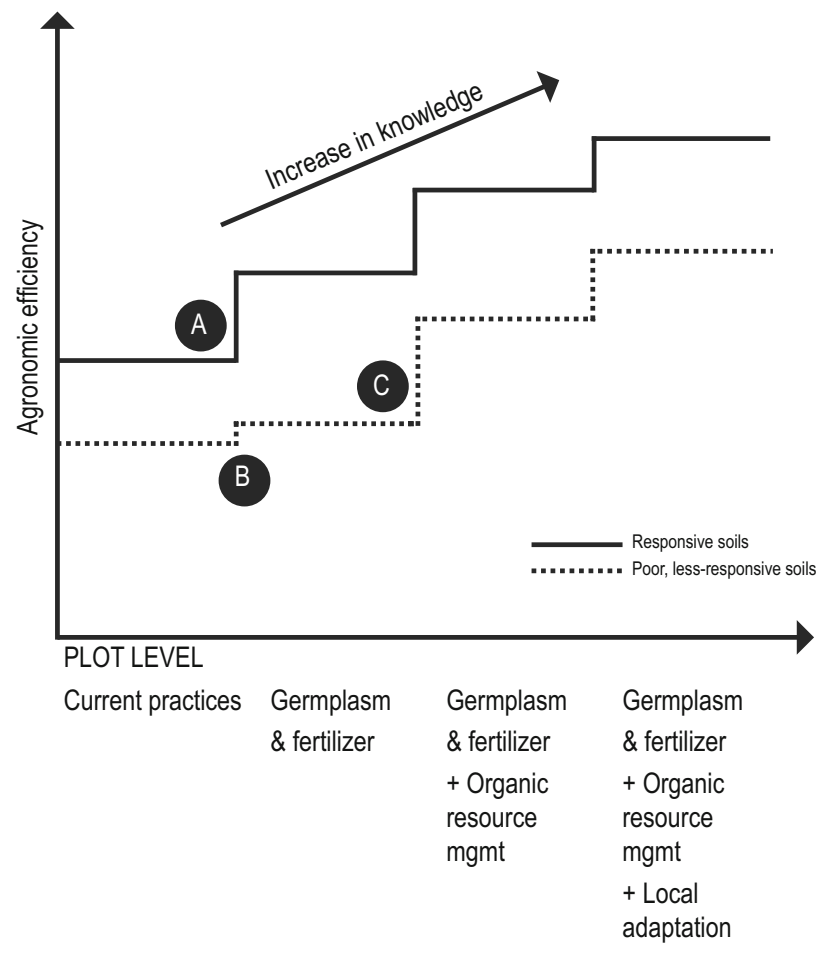

Move towards 'complete ISFM'

Fig. 6 Integrated soil fertility management (ISFM) approach to improving crop productivity and nutrient use efficiency (from Vanlauwe et al. 2015) Soils are classified either as "responsive soils" shown as the solid line path or "less responsive soils" depicted as the dotted line path. Soils in class A, which represents the position of most sub-Saharan African soils, are on the responsive soils path and would be expected to show increased yield if each phase of integrated soil fertility management (ISFM) could be implemented. Class B soils are on the less responsive path and are expected to show little or no response to fertilizer and improved germplasm treatments, moving them only to the position of class $\mathrm{C}$ soils. Only when these soils receive organic resource management to address the causes of their non-responsiveness to fertilizers, can yield be expected to increase in these soils, as indicated by the dotted line upward steps to the right of position $\mathrm{C}$ 
fertilizer and improved crop germplasm, such as seed sources and propagules for planting. Organic inputs, whether they are animal manures, green manures such as legume cover crops or trees, or composts, can increase NUE, water storage and availability in the soil, and build soil organic matter (Palm et al. 2007; Vanlauwe et al. 2015).

Most agriculture in sub-Saharan Africa is rainfed. Although one hears of droughts and crop failures throughout the region on a recurring basis, it is lack of rain during critical periods of crop growth (flowering, grain filling) that can more frequently affect yields - even when it is not a drought year (Sileshi et al. 2011). Adaptation to these agricultural droughts is critical to increasing and maintaining crop productivity. Soil management practices such as modified tillage, crop residue management, and soil nutrient status have been shown to increase water use efficiency and are a key means of adaption to periods of water stress (Hatfield et al. 2001). Nutrient additions increased water use efficiency up to $25 \%$ and conferred significant resilience of yields during "drought" years (Sileshi et al. 2008). Studies in Africa have shown an increase in yields and rain use efficiency (RUE) with the application of mineral fertilizers, legume tree crops, or their combination (Sileshi et al. 2011).

A concern often mentioned regarding an increase in fertilizer use in sub-Saharan Africa, often couched as "avoiding the mistakes" of the developed world, is the possibility of environmental contamination of water resources and emissions of nitrous oxide, a potent greenhouse gas. High nitrate levels in groundwater can be a health hazard in these small holder rural populations where shallow ground water is often the primary source of drinking water. Nitrogen leaching along with surface runoff of nitrogen and phosphorus into streams and lakes can lead to eutrophication and decreases in aquatic biodiversity, including fisheries, which is another important source of protein for many subsistence dwellers. It is important to consider these environmental impacts as the African Green Revolution takes off at larger scales in sub-Saharan Africa; however, it is equally important to put this into the context of the rates of $\mathrm{N}$ application. Currently, there is a deficit of $\mathrm{N}$ in agricultural systems, with the soils being mined through crop harvests and little replacement through fertilizers or manures (Vitousek et al. 2009). A goal of the African Green Revolution has been to increase total fertilizer $(\mathrm{N}, \mathrm{P}, \mathrm{K})$ inputs from an average of less than $10 \mathrm{~kg}$ per hectare per year in 2005 (with less than half of that being $\mathrm{N}$ ) to $50 \mathrm{~kg}$ by 2015 . Most national recommendations for $\mathrm{N}$ fertilizer are less than $80 \mathrm{~kg} \mathrm{~N}$ per hectare. Research to date indicates that $\mathrm{N}$ leaching may not increase significantly in clayey soils but will increase in sandy soils even at low rates of $\mathrm{N}$ application (Tully et al. 2015). Nitrous oxide emissions with increasing rates on $\mathrm{N}$ fertilizer application also do not seem to increase significantly until 100 or more $\mathrm{kg} \mathrm{N}$ per hectare is applied (Hickman et al. 2015). Reasons for these relatively low losses are that the crops are taking up the available $\mathrm{N}$ and only at higher rates is there excess $\mathrm{N}$ available for losses. So although we need to be aware of the environmental impacts of increased $\mathrm{N}$ applications, there is increasing evidence that at rates below $100 \mathrm{~kg} \mathrm{~N}$ per hectare $\mathrm{N}$ losses may remain low, at least on clayey soils.

\section{Policies to advance "more food, low pollution"}

\section{Addressing farmers' decision-making and farmers' perceptions of risk}

Although some studies have documented that most fertilizer recommendations are made by private sector crop advisors (Stuart et al. 2014), other surveys emphasize that farmers mostly make the decisions about fertilizer applications (Osmond et al. 2014). Regardless, it is critical that everyone involved in agriculture, whether the fertilizer manufacturers and distributors, the crop advisors, or the public sector (i.e., extension, USDA-NRCS, soil and water districts) work together to ensure adoption of recommendations that optimize crop yield while limiting the negative environmental consequences of $\mathrm{N}$ losses into the environment. While nutrient plans need to use the best science regarding the most appropriate $\mathrm{N}$ rates, sources, placement, and timing, these plans need to be streamlined and easy to utilize; otherwise, nutrient plans are not implemented. New technologies, such as sensors, field-based data, and new chemical tests, may provide opportunities for industry and universities to make better and more precise $\mathrm{N}$ rate recommendations. Research has shown that procedural best management practices, requiring repeated time investments, are more difficult for farmers to implement than are structural best management practices, which often require only one-time device installations, (Osmond et al. 2012). New technologies may reduce the time associated with procedural BMPs, such as precision nutrient management. New technologies offered by fertilizer retailers may enable them to sell services in addition to products, thus maintaining the profitability of their business despite possibly selling less fertilizer. It is critical that everyone - academia, industry, and the public sector - provide consistent nutrient management recommendations to farmers in order to reduce inconsistent and conflicting messages.

The primary reason that farmers often apply more $\mathrm{N}$ fertilizer to their fields than recommended by a crop advisor or by their a governmental agricultural extension service is that they view the extra fertilizer as a relatively cheap "insurance policy" for obtaining the best crop yield possible given the weather and other uncertainties. Although there are many management tools available to farmers to help them estimate optimal fertilizer application rates, they often do not fully trust these recommendations and apply a bit more "for good measure." Unfortunately, in most years, this fertilizer is not used by the crops and is lost to the environment as forms of water and air pollution. In perhaps one out of five years or so, the conditions are ideal for a bumper crop, and the farmer perceives that he has been financially rewarded for applying the extra fertilizer 
that year, perhaps with a profit margin that more than makes up for the extra fertilizer applied in other years as well. Hence, the additional fertilizer costs may be rational from the farmer's economic perspective, even though excess fertilizer is lost in most years. The farmer's fear of not obtaining good yield could, in theory, be addressed by other "insurance" approaches. However, a pilot nutrient best management practice endorsement insurance program by the USDA Risk Management agency in 2003 was not successful, and a pilot program in Pennsylvania to pay farmers to apply less $\mathrm{N}$ fertilizer also resulted in significant negative economic returns (Green et al. 2011). Shifting risks and costs of potential suboptimal yields from farmers to other entities, whether insurance products or taxpayers, remains an area of socioeconomic research and pilot projects.

\section{Market approaches}

In other sectors, market approaches have been used to distribute costs among polluters, rewarding those who find ways of reducing pollution and penalizing those who do not. An example is the U.S. Environmental Protection Agency's Clean Air Market for nitrogen and sulfur oxide emissions from energy and industrial sectors, which successfully marshaled the creativity of the private sector to develop low-cost pollution control technologies while imposing declining caps on emissions (USEPA 2015). Companies that responded to the financial incentive to reduce their emissions below their allowed permits were able to profit from selling their unused emission permits to other companies who needed to purchase additional emission permits, thus paying for their additional air pollution. As caps have been lowered over time, pollution has declined, using technological innovations spurred by this market trading. More recently, interest has been focused on greenhouse gas market trading, including payments to farmers for reducing their nitrous oxide $\left(\mathrm{N}_{2} \mathrm{O}\right)$ emissions. For farmers to qualify, they must follow protocols that are designed to increase nitrogen use efficiency, which may also reduce $\mathrm{N}$ fertilizer costs. A pilot project in Michigan that reduces $\mathrm{N}$ input to corn, developed by Michigan State University (MSU) and the Electric Power Research Institute (EPRI), generated the world's first $\mathrm{N}_{2} \mathrm{O}$ offsets in spring 2014 (Winsor 2014). Efforts are underway to expand on this initiative (e.g., Delta Institute's Nitrogen Credit Program), but large-scale adoption will require overcoming several challenges, including lack of information and understanding, skepticism about sharing data, costs of implementing the protocols and verifying emission reductions, and low prices currently paid for emission offsets (Davidson et al. 2014, Delta Nitrogen Credit Program 2015).

Similar market approaches for water quality credits are being piloted by the Ohio River Basin Trading Project (EPRI 2014). Farmers are able to receive payments for adopting best management practices designed to reduce runoff of $\mathrm{N}$ and $\mathrm{P}$ from their fields. So far, the purchasers of these $\mathrm{N}$ credits have been utility companies seeking to offset nitrogen oxide emissions, which, although they are initially emitted as air pollutants, will fall onto land and water bodies downwind of their plants. Regardless of whether the $\mathrm{N}$ atoms initially enter the environment as an air or water pollutant, they are transformed in the environment so that emitted $\mathrm{N}$ can affect both air and water quality. In the future, it may also be possible to integrate water quality market payments with greenhouse gas reduction payments, including the $\mathrm{N}_{2} \mathrm{O}$ emissions payments described in the previous paragraph, in order to make the combined package more economically favorable for farmer adoption of nutrient best management practices.

\section{Commodity supply chains}

Relatively new players in the agricultural nutrient management nexus are the private sector companies that make up the supply chains linking farmers to consumers. Driven largely by voluntary corporate sustainability goals, several corporations involved in processing and marketing food products are partnering with universities, environmental non-profit groups, and government agencies to define, measure, and develop a supply-chain system for agricultural sustainability, including reduced emissions of greenhouse gas and reduced runoff of nitrate. For example, Field to Market is a multistakeholder association that has developed an online "fieldprint calculator" to index the effects of farmers' agronomic practices (Field to Market 2012). This tool enables farmers to compare their sustainability performance relative to their own past performance and to an anonymous list of peer farmers in the same region. One of the objectives is to empower farmers with the knowledge and tools they need to implement conservation agriculture practices that preserve natural resources, reduce costs, and increase crop yields and farm profitability in the long term. Walmart, one of the members of Field to Market and the largest grocery retailer, announced a new fertilizer initiative in 2013, that requires companies who use commodity grains to develop fertilizer optimization plans across 14 million acres of US farmland by 2020 (Walmart 2013). When Walmart analyzed the biggest sources of greenhouse gases for its top 100 products, it found that fertilizer was the number one source for approximately half of those products. As of early 2015, 15 of Walmart's major suppliers, who represent $30 \%$ of food and beverage sales in North America, have developed fertilizer optimization plans. Walmart's demand for food commodities, and hence, its potential influence on supply chains is significant, but there are many links in these supply chains that must be included, such as its supplier companies (like Kellogg's), which usually get their grain from aggregator companies that own grain elevators and mills, which, in turn, have purchased grain from farmers. Working through these complex supply chains 
requires innovative approaches to measurement and data sharing. The Environmental Defense Fund (EDF), also a member of Field to Market, is working with agronomic and environmental experts from academia, industry, and government to develop simple metrics, such as estimates of the fraction of fertilizer- $\mathrm{N}$ inputs contained in the crop- $\mathrm{N}$ exports, which farmers will be able to readily adopt for reporting to their grain purchasers. Information about grower adoption of these options and the resulting impacts on water quality and greenhouse gas emissions must also be collected and tracked across broad sourcing areas to facilitate supply-chain reporting. Persuading major food companies and agribusinesses to implement complementary approaches is an innovative, nonregulatory approach to bring the adoption of conservation agriculture to scale and to achieve success in terms of both the economic outcomes for growers and retailers and the sustainability benefits for water quality and climate stability.

\section{Innovative cropping systems}

Tropical cropping and farming systems are generally more diverse than the one or two crop rotations found in temperate regions. These diverse tropical systems are characterized by intercropping (in the same field during the same season) two or more crops or even trees. Cereal and legume intercrops are found throughout the tropics, with corn and beans perhaps being the most common. Other "grain legumes" intercropped with cereals include peanuts, soybeans, and other types of "beans." Legume crops fix atmospheric $\mathrm{N}$ through symbiotic relationship with nitrogen fixing bacteria in their roots, but the amount of $\mathrm{N}$ fixed or the amount that remains in the field after harvesting the beans is generally small (Giller 2001). Nevertheless, while the benefit to subsequent crops is usually less than $20 \mathrm{~kg} \mathrm{~N}$ per hectare, and although this may seem small, it can result in increased yields of these crops. Recent varieties of soybean that produce significant amounts of leaf biomass (Krisnawati and Adie 2015), which could remain on the field as crop residue that nourishes the next crop with its nutrients, show promise in terms of crop production as well as the subsequent $\mathrm{N}$ benefits. Leguminous trees and cover crops in tropical cropping systems fix much more N (100$200 \mathrm{~kg} \mathrm{~N}$ per hectare per year) than grain legumes, providing significant $\mathrm{N}$ that promotes yield increases to succeeding crops (Sileshi et al. 2008). Despite the $\mathrm{N}$ benefit as well as other benefits such as fuelwood, fodder, and weed control from some of these tree and herbaceous legumes, rates of adoption have been disappointing in many places (Kiptot et al. 2007; Keil et al. 2005). Reasons for the low adoption include the opportunity costs of land, labor, and time in producing plants that do not contribute directly to household food security or income.
Making nutrient supply and management affordable in the developing world

The high cost of fertilizers and low value cost ratios (VCR; the economic value of increased crop yield divided by the cost of the fertilizer) for the use of fertilizers on cereal crops are a deterrent to their widespread use in sub-Saharan Africa (Kihara et al. 2015). Part of the reason for the low VCR is that inappropriate fertilizer blends are recommended, resulting in lower yields and returns or higher costs if nutrients are applied that are not needed for the particular crop-soil. There is increasing interest by national institutions, policy makers, and companies for better targeting fertilizer blends and rates to overcome some of these problems (part of the 4Rs). Providing better fertilizers and fertilizer recommendations is only part of the solution; the costs of these fertilizers will likely still be prohibitive in many if not most situations for small holder farmers in subSaharan Africa. Although there are ongoing debates on subsidies for fertilizers for small holders in sub-Saharan Africa (Jayne and Rashid 2013; and see section above on case study 2), without them, the uptake of fertilizers and increasing yields will be slow in the region. Improved policies and implementation of these subsidies will be required to garner the support needed for them to be effective. Providing easy access credit, warehouse receipts systems, and index-based crop insurance programs could be included as part of these packages to reduce the upfront costs and reduce the risks taken by smallholder farmers.

\section{Livestock NUE}

The discussion here has been focused mostly on nutrient use efficiency (NUE) of crop production, but more attention is also needed on nutrient management in livestock operations. Indeed, soybeans and some cereals have high NUE as crops, but when fed to livestock, efficient recycling of the manure- $\mathrm{N}$ is often challenging, resulting in lower integrated NUE for the crop-livestock production system, despite recent improvements in livestock operation efficiency (Powell and Rotz 2015). Animal and crop production systems have been decoupled in many developed countries, with enormous volumes of manure produced at locations distant from where there is sufficiently large demand for nutrient additions to croplands. The economic value of the manure often is not high enough to justify the costs of transporting it to distant croplands. Recoupling animal and crop production systems geographically and integrating them operationally in the developed world would improve the overall efficiency of those food 
production systems. In most developing countries of the tropics, the livestock and cropping systems are still quite integrated (Valbuena et al. 2012), with residue and manure management remaining within the same farm. Keeping this integration in place, as intensification occurs, will be a challenge, yet critical to nutrient use efficiency.

\section{Dietary choices}

Individual choice can also play a large role in reducing $\mathrm{N}$ pollution. Protein is an essential part of the human diet and protein contains $\mathrm{N}$. The types of protein we choose to eat can greatly impact $\mathrm{N}$ pollution as the amount of reactive- $\mathrm{N}$ needed to create one serving of protein varies greatly. The amount of $\mathrm{N}$ required to produce one serving of plant-based proteins such as beans is significantly less than the amount of $\mathrm{N}$ required for poultry, which, in turn, is less than the amount required for beef production (Leip et al. 2014). One metric to gauge dietary and other lifestyle choices is the $\mathrm{N}$ footprint (Leach et al. 2012).

Each individual's $\mathrm{N}$ footprint can be thought of as the amount of reactive- $\mathrm{N}$ released to the environment as a result of their choices about how to consume resources (Galloway et al. 2014). Nitrogen footprint calculators include data about two primary areas of resource consumption: energy and food, which includes both food consumption and production. Energy consumption considers individual choices regarding energy use, transportation, storm water, and the purchase of $\mathrm{N}$ offsets. Food consumption is defined as the amount of $\mathrm{N}$ that enters a human mouth. The average per capita consumption of $\mathrm{N}$ in food in Tanzania $\left(\sim 2 \mathrm{~kg} \mathrm{~N}\right.$ year $\left.^{-1}\right)$ is less than half that of the US $\left(\sim 5 \mathrm{~kg} \mathrm{~N}_{\text {year }}{ }^{-1}\right)$, with the recommended consumption for a healthy diet of an average adult falling in the middle (2.5-3.5 kg N year ${ }^{-1}$; Galloway et al. 2014), suggesting that the average American consumes more $\mathrm{N}$ than needed and the average Tanzanian is undernourished. The $\mathrm{N}$ footprint also considers calculations of food production, including all of the $\mathrm{N}$ lost to the environment during the food production process. Across the globe, food production comprises the majority of an average individual's $\mathrm{N}$ footprint (Galloway et al. 2014). In the US, the per capita $\mathrm{N}$ footprint is $39 \mathrm{~kg} \mathrm{~N}$ year $^{-1}$ with nearly $60 \%$ of this footprint coming from food production; in Tanzania, the per capita $\mathrm{N}$ footprint is just $15 \mathrm{~kg} \mathrm{~N}$ year $^{-1}$ with $80 \%$ of this footprint due to food production (Galloway et al. 2014). There are multiple ways to reduce $\mathrm{N}$ footprints, including the reduction of food waste and overall energy consumption, improved composting and food recycling, selection of sustainably produced foods with low $\mathrm{N}$ footprints, use of sustainable modes of transportation, enhancement of sewage and storm water treatment, and the purchase of $\mathrm{N}$ offsets (Leach and Andrews 2015).

\section{Sustainable development goal indicators}

The United Nations has adopted a list of 17 sustainable development goals, each with specific targets for 2030. One of these goals is: "End hunger, achieve food security and improved nutrition, and promote sustainable agriculture." At the time of this writing, the UN is still evaluating a list of proposed quantitative indicators for each of these goals. One of the nine proposed indicators for the sustainable agriculture goal is: "Nitrogen use efficiency in food systems." For this indicator to be effective, countries will need to be encouraged to routinely collect data on their $\mathrm{N}$ management in crop and

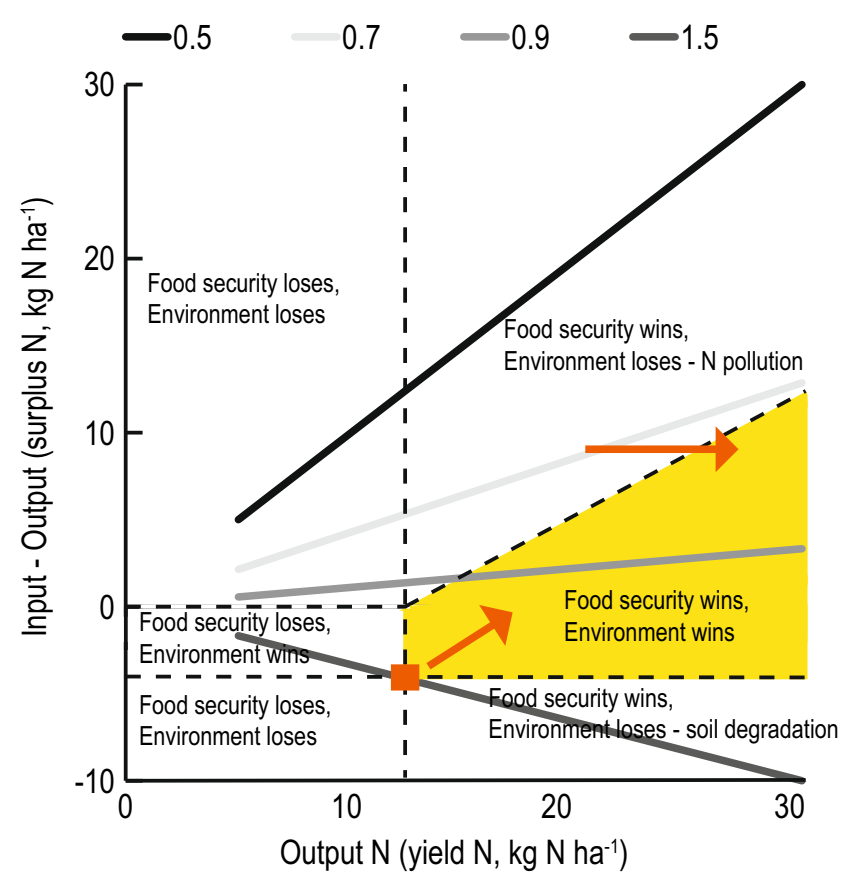

Fig. 7 Plotting the trajectory of a nation's $N$ surplus (N inputs as fertilizer and manure minus $\mathrm{N}$ outputs as crop harvest, plotted on the $Y$ axis) and $\mathrm{N}$ in crop harvest yield ( $\mathrm{N}$ outputs plotted on the $X$ axis), can illustrate whether is country in on a pathway of sustainable agricultural development. A hypothetical example, depicted by the orange square, is shown for a country with average crop yield-N of only $12 \mathrm{~kg} \mathrm{~N}$ per hectare per year, much of which comes from mining the soil of its nutrients (negative values for $\mathrm{N}$ surplus) due to lack of affordable fertilizers and manures. This results in soil degradation as well as low crop productivity, so both food security and environmental quality goals are not met. As the country develops its agricultural sector, finds affordable sources of nutrient additions to soils, and increases crop yield, it also needs to manage for relatively high nutrient use efficiency (NUE). If it can keep NUE between about 0.7 and 0.9 (shown as the two lightest shades of gray lines) as it moves in the direction of the orange arrows to the upper right in the graph, but staying within the shaded yellow area, then food security goals can be met without increasing $\mathrm{N}$ surplus to unacceptable levels that would compromise environmental quality (color figure online) 
livestock production to be used to trace trajectories of nitrogen use efficiency (Fig. 7). Just as protocols established by the Intergovernmental Panel on Climate Change have permitted nations to gauge their progress and commitment for reducing greenhouse gas emissions, protocols for measuring and reporting on a NUE indicator for sustainable agriculture would enable governments to assess their progress in achieving food security goals while maintaining environmental quality (Zhang et al. 2015).

\section{Conclusion}

The MoFoLoPo goals of producing more food with low pollution will not be achieved by technological developments alone, but will also require recognition of the complex economic and social factors affecting farmer decision-making and national policy priorities. This may require, for example, tailoring regulations, incentives, and outreach to local conditions, administered and enforced by local entities, and where local "buy-in" has been obtained. The two case studies presented here are very different in terms of uses of technology and the intensity of inputs, and yet both illustrate the importance of targeting efforts to local conditions. Much can be done with existing technologies, provided that socioeconomic conditions can be made favorable for farmer adoption. New technologies will be more likely implemented if they make best management practices easier for farmers to understand and to implement and less expensive.

For developing countries to grow their agricultural productivity without impairing environmental integrity, national and international communities will need to facilitate technology transfer and promote agricultural innovation. Increased availability of nutrient sources, including fertilizers, animal manure, compost, and $\mathrm{N}$-fixing crops are needed, but must be used with well-informed, science-based management practices that maintain high nutrient use efficiency.

Whether irrigated or rain-fed, and whether large-scale and intensive or small-scale and subsistence-oriented, the nexus of food, water, and energy is inherently related to nutrient management. Water and nutrients are often both limiting to agricultural productivity, and increasing the use efficiency of one generally enhances the use efficiency of the other and the overall resilience of the cropping system. Improving NUE in all types of agriculture will require cross-disciplinary and cross sectorial partnerships, such as (1) integrating research and development of innovative agricultural technology and management systems with socio-economic research and outreach; (2) promoting knowledge and data sharing among private and public sectors to advance science-based nutrient management; and (3) analyzing the nexus of food, water, nutrients, and energy management to optimize the net benefits to farmers, the environment, and society. Demand for food to improve nourishment of a growing human population ensures that the global $\mathrm{N}$ cycle will remain intensified relative to the pre-industrial era, but knowledge-based agriculture can limit the unintended environmental consequences of food production while pursuing the quest for sustainable development.

Acknowledgments This work was supported by NSF Research Coordination Network award DEB-1049744 and NSF Prime Award OISE0968211. This is Scientific Contribution number 5152 of the University of Maryland Center for Environmental Science Appalachian Laboratory.

Open Access This article is distributed under the terms of the Creative Commons Attribution 4.0 International License (http:// creativecommons.org/licenses/by/4.0/), which permits unrestricted use, distribution, and reproduction in any medium, provided you give appropriate credit to the original author(s) and the source, provide a link to the Creative Commons license, and indicate if changes were made.

\section{References}

Abendroth LJ, Elmore RW, Boyer MJ, Marlay SK (2011) Corn growth and development. PMR 1009. Iowa State University Extension, Ames

Black RE, Allen LH, Bhutta ZA, Caulfield LE, de Onis M, Ezzati M, Mathers C, Rivera J (2008) Maternal and child undernutrition: global and regional exposures and health consequences. Lancet 371:243-260

Bodirsky BL, Popp A, Lotze-Campen H, Dietrich JP, Rolinski S, Weindl I, Schmitz C, Müller C, Bonsch M, Humpenöder F, Biewald A, Stevanovic M (2014) Reactive nitrogen requirements to feed the world in 2050 and potential to mitigate nitrogen pollution. Nat Commun 5:3858

Bosch DJ, Cook ZL, Fuglie KO (1995) Voluntary versus mandatory agricultural policies to protect water quality: adoption of nitrogen testing in Nebraska. Rev Agric Econ 17:13-24

Camargo JA, Alonso A (2006) Ecological and toxicological effects of inorganic nitrogen pollution in aquatic ecosystems: a global assessment. Environ Int 32(6):831-849

Carletto G, Ruel M, Winters P, Zezza A (2015) Farm-level pathways to improved nutritional status: introduction to the special issue. J Dev Stud 51:945-957

Cassman KG, Dobermann AD, Walters D (2002) Agroecosystems, nitrogen use efficiency, and nitrogen management. Ambio 31(2):132140

Central Platte Natural Resources District (2014) Groundwater Management Area Plan. http://www.cpnrd.org/GW\%20Quality\% 20Mgnt $\% 20$ Controls.pdf. Accessed 9 Oct. 2014

Cowling E, Erisman JW, Smeulders SM, Holman SC, Nicholson BM (1998) Optimizing air quality management in Europe and North America: justification for integrated management of both oxidized and reduced forms of nitrogen. Environ Pollut 102:599-608

David MB, Flint CG, Gentry LE, Dolan MK, Czapar GF, Cooke RA, Lavaire T (2015) Navigating the socio-bio-geo-chemistry and engineering of nitrogen management in two Illinois tile-drained watersheds. J Environ Qual 44:368-381. doi:10.2134/jeq2014.01.0036

Davidson EA, David MB, Galloway JN, Goodale CL, Haeuber R, Harrison RA, Howarth RW, Jaynes DB, Lowrance RR, Nolan BT, Peel JL, Pinder RW, Porter E, Snyder CS, Townsend AR, Ward MH (2012) Excess nitrogen in the U.S. environment: trends, risks, and solutions. Issues in Ecology, Report Number 15, Ecological Society of America

Davidson EA, Galloway JN, Millar N, Leach AM (2014) N-related greenhouse gases in North America: innovations for a sustainable future. Curr Opin Environ Sustain 9-10:1-8 
Davidson EA, Suddick EC, Rice CW, Prokopy LS (2015) More food, low pollution (Mo Fo Lo Po): a grand challenge for the 21st century. J Environ Qual 44:305-311

Deckelbaum R, Palm C, Mutuo P, DeClerck F (2006) Econutrition: implementation models from the Millennium Villages Project in Africa. Food Nutr Bull 27:335-42

Delta Nitrogen Credit Program (2015) Nitrogen credit program. http:// www.deltanitrogen.org. Accessed 1 Sept 2015

Denning G, Kabambe P, Sanchez P, Malik A, Flor R, Harawa R, Nkhoma P, Zamba C, Banda C, Magombo C, Keating M, Wangila J, Sachs J (2009) Input subsidies to improve smallholder maize productivity in Malawi: toward an African Green Revolution. Plos Biol 7:2-10

Dorward D, Chirwa E, Kelly V, Jayne T, Slater R, Boughton D (2008) Evaluation of the 2006/7 agricultural input subsidy programme, Malawi. Final report. Ministry of Agriculture and Food Security of Malawi

EPRI (2014) EPRI Ohio River Basin Water Quality Trading Project. http://wqt.epri.com. Accessed 1 Oct 2015

Erisman JW, Galloway JN, Seitzinger S, Bleeker A, Butterbach-Bahl K (2011) Reactive nitrogen in the environment and its effect on climate change. Curr Opin Environ Sustain 3:281-290

Erisman JW, Galloway JN, Seitzinger S, Bleeker A, Dise NB, Petrescu R, Leach AM, de Vries W (2013) Consequences of human modification of the global nitrogen cycle. Philos Trans R Soc B 368(1621). doi:10.1098/rstb.2013.0116

Exner ME, Perea-Estrada H, Spalding RF (2010) Long-term response of groundwater nitrate concentrations to management regulations in Nebraska's Central Platte Valley. Sci World J 10:286-297. doi:10. 1100/tsw.2010.25

Ferguson RB (2015) Groundwater quality and nitrogen use efficiency in Nebraska's Central Platte River Valley. J Environ Qual 44(2):449 459. doi:10.2134/jeq2014.02.0085

Field to Market (2012). Environmental and socioeconomic indicators for measuring outcomes of on-farm agricultural production in the United States: second report (Version 2). http://www.fieldtomarket. org. Accessed 1 Oct 2015

Firestone MK, Davidson EA (1989) Microbiological basis of NO and $\mathrm{N} 2 \mathrm{O}$ production and consumption in soil. In: Andreae MO, Schimel DS (eds) Exchange of trace gases between terrestrial ecosystems and the atmosphere. Wiley, Berlin, pp 7-21

Galloway JN (1998) The global nitrogen cycle: changes and consequences. Environ Pollut 102:15-24

Galloway JN, Aber JD, Erisman JW, Seitzinger SP, Howarth RW, Cowling EB, Cosby J (2003) The nitrogen cascade. Bioscience 53(4):341-356

Galloway JN, Winiwarter W, Leip A, Leach AM, Bleeker A, Erisman JW (2014) Nitrogen footprints: past, present and future. Environ Res Lett 9:115003. doi:/10.1088/1748-9326/9/11/115003

Giller KE (2001) Nitrogen fixation in tropical cropping systems, 2nd edn. CAB International, New York

Graham R (2008) Micronutrient deficiencies in crops and their global significance. In: Alloway B (ed) Micronutrient deficiencies in global crop production. Springer, New York, pp 41-62

Green T, Cubie J, Ressl R, Anderson M, Baird J, Brandt B, McCarthy J, Kieser M, Gilbert J (2011) Nitrogen management performance guarantee system for corn producers in Pennsylvania: feasibility to improve water quality in Chesapeake Bay. America Farmland Trust, Washington DC

Grosse SD, Roy K (2008) Long-term economic effect of early childhood nutrition. Lancet 371:365-366

Hatfield JL, Venterea RT (2014) Enhanced efficiency fertilizers: a multisite comparison of the effects on nitrous oxide emissions and agronomic performance. Agron J 106:679-680

Hatfield JL, Sauer TJ, Prueger JH (2001) Managing soils to achieve greater water use efficiency: a review. Agron J 93:271-280
Hickman JE, Palm CA, Tully KL, Diru W, Groffman PM (2015) A nitrogen tipping point in tropical agriculture: avoiding rapid increases in nitrous oxide fluxes with intensification. J Geophys Res: Biogeosci 120:938-951. doi:10.1002/2015JG002913

Howarth R, Anderson D, Cloern J, Elfring C, Hopkinson C, Lapointe B, Malone T, Marcus N, McGlathery K, Sharpley A, Walker D (2000) Nutrient pollution of coastal rivers, bays, and seas. ESA Issues Ecol $7: 1-15$

Jayne TS, Rashid S (2013) Input subsidy programs in sub-Saharan Africa: a synthesis of recent evidence. Agric Econ 44:547-562

Keil A, Zeller M, Franzel S (2005) Improved tree fallows in smallholder maize production in Zambia: do initial testers adopt the technology? Agrofor Syst 64:225-236

Kihara J, Huising J, Nziguheba G, Waswa BS, Njoroge S, Kabambe V, Iwuafor I, Kibunja C, Esilaba AO, Coulibaly A (2015) Maize response to macronutrients and potential for profitability in subSaharan Africa. Nutr Cycl Agroecosyst. doi:10.1007/s10705-0159717-2

Kiptot E, Hebinck P, Franzel S, Richards P (2007) Adopters, testers or pseudo-adopters? Dynamics of the use of improved tree fallows by farmers in western Kenya. Agric Syst 94:509-519

Korus JT, Howard LM, Young AR, Divine DP, Burbach ME, Jess JM, Hallum DR (2013) The groundwater atlas of Nebraska, 3rd edn. School of Natural Resources, Institute of Agriculture and Natural Resources, University of Nebraska-Lincoln, Lincoln, NE, Conservation and Survey Division

Krisnawati A, Adie MM (2015) Variability of biomass and harvest index from several soybean genotypes as renewable energy source. Energy Procedia 65:14-21

Leach A, Andrews J (2015) Calculating the campus nitrogen footprint. NECSC conference 2015. Paper 10. http://scholarworks.umass.edu/ cgi/viewcontent.cgi? article $=1009 \&$ context $=$ necsc2015. Accessed 2 Oct 2015

Leach AM, Galloway JN, Bleeker A, Erisman JW, Kohn R, Kitzes R (2012) A nitrogen footprint model to help consumers understand their role in nitrogen losses to the environment. Environ Dev 1: 40-66. doi:10.1016/j.envdev.2011.12.005

Leip A, Leach A, Musinguzi P, Tumwesigye T, Olupot G, Tenywa JS, Mudiope J, Hutton O, Cordovil CMDS, Bekunda M, Galloway J (2014) Nitrogen-neutrality: a step towards sustainability. Environ Res Lett 9:115001. doi:10.1088/1748-9326/9/11/115001

Liu J, You L, Amini M, Obersteiner M, Herrero M, Zehnder AJB, Yang H (2010) A high-resolution assessment on global nitrogen flows in cropland. Proc Natl Acad Sci 107:8035-8040

Osmond D, Meals D, Hoag D, Arabi M (2012) How to build better agricultural conservation programs to protect water quality: the NIFA-CEAP experience. Soil and Water Conservation Society, Ankeny, IA

Osmond DL, Hoag DLK, Luloff AE, Meals DW, Neas K (2014) Farmers' use of nutrient management: lessons from watershed case studies. J Environ Qual 44(2):382-390. doi:10.2134/jeq2014.02.0091

Palm CA, Sanchez PA, Ahmed S, Awiti A (2007) Soils: a contemporary perspective. Annu Rev Environ Resour 32:99-129

Powell J, Rotz C (2015) Measures of nitrogen use efficiency and nitrogen loss from dairy production systems. J Environ Qual 44:336-344

Prokopy LS, Floress K, Kllatthar-Weinkauf D, Baumgart-Getz B (2008) Determinants of agricultural best management practice adoption: evidence from the literature. J Soil Water Conserv 63:300-311. doi: $10.2489 /$ jswc. 63.5 .300

Rabalais NN, Turner RE, Scavia D (2002) Beyond science into policy: Gulf of Mexico hypoxia and the Mississippi River. Bioscience 52:129-142

Rajkovich SR, Crozier CR, Smyth TJ, Crouse D, Osmond DL (2015) Updating North Carolina corn yields and nitrogen recommendations to match current production practices and new hybrids. Crop, Forage, andTurfgrass Management 1(1). doi:10.2134/cftm2014. 0085 
Ravishankara AR, Daniel JS, Portmann RW (2009) Nitrous oxide $\left(\mathrm{N}_{2} \mathrm{O}\right)$ : the dominant ozone-depleting substance emitted in the 21 st century. Science 326(5949):123-125

Remans R, Pronyk PM, Fanzo JC, Chen J, Palm CA, Nemser B, Muniz M, Radunsky A, Abay AH, Coulibaly M, Mensah-Homiah J, Wagah M, An X, Mwaura C, Quintana E, Somers MA, Sanchez PA, Sachs SE, McArthur JW, Sachs JD, Millennium Villages Study Group (2011) Multisector intervention to accelerate reductions in child stunting: an observational study from 9 sub-Saharan African countries. Am J Clin Nutr 94:1632-1642

Sanchez PA, Swaminathan MS (2005) Hunger in Africa: the link between unhealthy people and unhealthy soils. Lancet 365:442-444

Sanchez PA, Palm CA, Sachs JD, Denning G, Flor R, Harawa R, Jama B, Kiflemariam T, Konecky B, Kozar R, Lelerai E, Malik A, Modi V, Mutuo P, Teklehaimanot A, Wang K, Wangila J, Zomba C (2007) The African Millennium Villages. Proc Natl Acad Sci 104(43): $16775-16780$

Sawyer J, Nafziger E, Randall G, Bundy L, Rehm G, Joern B, Laboski C, Hoeft R, Mullen R, Killorn R, Brouder S (2006) Concepts and rationale for regional nitrogen rate guidelines for corn. http://www. extension.iastate.edu/Publications/2015.pdf Accessed 1 Oct 2015

Shapiro CA, Ferguson RB, Hergert GW, Wortmann CS, Walters DT (2008) Fertilizer suggestions for corn. University of NebraskaLincoln Extension Circular 117. http://www.ianrpubs.unl.edu/ epublic/live/ec117/build/ec117.pdf. Accessed 4 June 2014

Sileshi GW, Akinnifesi FK, Ajayi OC, Place F (2008) Meta-analysis of maize yield response to woody and herbaceous legumes in subSaharan Africa. Plant Soil 307:1-19

Sileshi GW, Akinnifesi FK, Ajayi OC, Muys B (2011) Integration of legume trees in maize-based cropping systems improves rain use efficiency and yield stability under rain-fed agriculture. Agric Water Manag 98:1364-1372

Smil V (1999) Nitrogen in crop production: an account of global flows. Glob Biogeochem Cycles 13:647-662

Smil V (2001) Enriching the Earth: Fritz Haber, Carl Bosch, and the transformation of food production. MIT Press, Cambridge, pp 1338

Smil V (2002) Nitrogen and food production: proteins for human diets. Ambio 31:126-131

Stuart D, Schewe RL, McDermott M (2014) Reducing nitrogen fertilizer application as a climate change mitigation strategy: understanding farmer decision-making and potential barriers to change in the US. Land Use Policy 36:210-218. doi:10.1016/j.landusepol.2013.08.011

Sutton MA, Bleeker A, Howard CM, Bekunda M, Grizzetti B, de Vries W, van Grinsven HJM, Abrol YP, Adhya TK, Billen G,. Davidson EA, Datta A, Diaz R, Erisman JW, Liu XJ, Oenema O, Palm C, Raghuram N, Reis S, Scholz RW, Sims T, Westhoek H \& Zhang FS, with contributions from Ayyappan S, Bouwman AF, Bustamante M, Fowler D, Galloway JN, Gavito ME, Garnier J, Greenwood S, Hellums DT, Holland M, Hoysall C, Jaramillo VJ, Klimont Z, Ometto JP, Pathak H, Plocq Fichelet V, Powlson D, Ramakrishna K, Roy A, Sanders K, Sharma C, Singh B, Singh U, Yan XY \& Zhang Y (2013) Our nutrient world: the challenge to produce more food and energy with less pollution. Global Overview of Nutrient Management. Centre for Ecology and Hydrology, Edinburgh on behalf of the Global Partnership on Nutrient Management and the International Nitrogen Initiative.
Townsend AR, Howarth RW, Bazzaz FA, Booth MS (2003) Human health effects of a changing global nitrogen cycle. Front Ecol Environ 1(5):240-246

Tully KL, Hickman J, McKenna M, Neill C, Palm C (2015) Effects of fertilizer on inorganic soil $\mathrm{N}$ in East African maize systems: vertical distributions and temporal dynamics. Ecological Applications, in press

United States Department of Agriculture National Agricultural Statistics Service (2014). Agricultural Resource Management Survey (ARMS). http://nass.usda.gov/Surveys/Guide_to_NASS_Surveys/ Ag_Resource_Management/index.asp. Accessed 1 May 2014

United States Environmental Protection Agency (2015) Clean air markets. http://www2.epa.gov/airmarkets. Accessed 7 Oct 2015

University of Nebraska Extension Service (1965) Nebraska water quality survey. University of Nebraska Extension Service, Lincoln

Valbuena D, Erenstein O, Homann-Kee Tui S, Abdoulaye T, Claessens L, Duncan AJ, Gérard B, Rufinoh MC, Teufeli N, Van Rooyenc A, Van Wijkh MT (2012) Conservation agriculture in mixed crop-livestock systems: scoping crop residue trade-offs in Sub-Saharan Africa and South Asia. Field Crop Res 132:175-184

Vanlauwe B, Descheemaker K, Giller KE, Huising J, Merckx R, Nziguheba G, Wendt J, Zingore S (2015) Integrated soil fertility management in sub-Saharan Africa: unravelling local adaptation. Soil 1:291-508

Vitousek PM, Aber J, Howarth RW, Likens GE, Matson PA, Schindler DW, Schlesinger WH, Tilman GD (1997) Human alteration of the global nitrogen cycle: causes and consequences. Issues in Ecology, Report Number 1, Ecological Society of America

Vitousek PM, Naylor R, Crews T, David MB, Drinkwater LE, Holland E, Johnes PJ, Katzenberger J, Martinelli LA, Matson PA, Nziguheba G, Ojima D, Palm CA, Robertson GP, Sanchez PA, Townsend AR, Zhang FS (2009) Nutrient imbalances in agricultural development. Science 324(5934): 1519-1520

Walmart (2013) Walmart highlights progress on the sustainability index. http://news.walmart.com/news-archive/2013/09/12/walmarthighlights-progress-on-the-sustainability-index. Accessed $30 \mathrm{Sept}$ 2015

Watts DB, Runion GB, Smith Nannenga KW, Torbert HA (2014) Enhanced-efficiency fertilizer effects on cotton yield and quality in the coastal plains. Agron J 106:745-752. doi:10.2134/agronj13. 0216

Weber C, McCann L (2015) Adoption of nitrogen-efficient technologies by U.S. corn farmers. J Environ Qual 44:391-401. doi:10.2134/ jeq2014.02.0089

Winsor S (2014) New nitrogen reduction trading program. http:// cornandsoybeandigest.com/fertilizer/new-nitrogen-reductiontrading-program. Accessed 30 Sept 2015

World Bank (2006) Repositioning nutrition as central to development. The World Bank, Washington DC, 23pp

Wuest SB, Cassman KG (1992) Fertilizer-nitrogen use efficiency of irrigated wheat: I. Uptake efficiency of preplant versus late-season application. Agron J 84:682-688

Zhang X, Davidson EA, Mauzerall DL, Searchinger TD, Dumas P, Shen Y (2015) Managing nitrogen for sustainable development. Nature 528:51-59 